A. S. Kucher,

Senior Lecturer;

ORCID: 0000-0001-5478-9463

A. V. Paulava,

$\mathrm{PhD}$ of Technical Sciences, Associate Professor, ORCID: 0000-0003-3216-9989

V. V. Maskva,

$\mathrm{PhD}$ of Technical Sciences, ORCID: 0000-0002-3754-607X

Yanka Kupala State University of Grodno

Scientific and practical centre for foodstuffs of the National academy of Sciences of

Belarus Minsk, Belarus

\title{
NON-TRADITIONAL AND NEW TYPES OF PRODUCTS USED IN THE PREPARATION OF CATERING PRODUCTS
}

The article describes new and non-traditional types of raw materials and food products used in the technology of preparing catering products.

Keywords: salad greens, onion vegetables, mushrooms, spices.

Relevance of the research topic. Cooking has been available to mankind since ancient times, and the development of culinary as a professional field is associated with the emergence of out-of-home nutrition enterprises. In the new society, new types of food raw materials required new processing methods and new recipes, based on a scientific approach to the technology of cooking new dishes. Due to this, canned and quick-frozen raw materials, which were processed on modern machines with sophisticated equipment, were widely used in many catering enterprises.

Formulation of the problem. The main task is to improve the quality, expand the assortment, increase the production of semi-finished products of a high degree of readiness, as well as introduce energy-saving technologies, improve sanitary and hygienic conditions. The focus is on new, rapidly reconstructed operations, the creation and implementation of new dishes that will meet the requirements of a balanced diet. All these tasks are equally faced by restaurants, cafes, canteens.

Analysis of recent research and publications. Scientific literature and regulatory information on non-traditional (new) types of food products and raw materials used in the preparation of catering products is analyzed.

Presenting main material. In catering, you can find a large number of unconventional and new types of raw materials, for example, the use of flowers for 
cooking. An example is geranium, from the leaves of which you can prepare a sorbet, or lavender, used in marinade for duck breast, as well as violet, which is candied and used as a dessert in France.

In gastronomy, new types of salad greens are widely used:

- oaklif (oak salad), which has a rich taste with a nutty flavor, is sensitive to temperature changes, color from green to purple. Combined with champignons, avocados, salmon, light dressings based on vegetable oil, citrus fruits, can act as a side dish for sea fish.

- lollorosso (red lettuce) have curly leaves, ranging in color from light green to purple-violet at the tips of the leaves, depending on the species. It is combined with almost all types of lettuce with a pronounced taste, as well as nuts, seeds and peanut butter.

- arugula has dark green elongated leaves, sometimes dentate, taste mustardnutty pepper. Usually used in salad mixes with a mild flavor. It is combined with balsamic, tomatoes, Mozzarella cheese, Parmesan, seafood, with pesto sauce.

- corn, which has a neat, small, rounded shape, dark green leaves, is characterized by a sweet nutty taste and a delicate aroma. It is combined with nuts, bacon, onions, citrus fruits.

- horseradish aroma, dark green leaves used as seasoning can be added to cold soups, in canapes, can act as a side dish for meat, game.

- mitsuna is used in mixes, Chinese and Japanese dishes. It is combined with parmesan and tomatoes.

- frieze - tastes with light bitterness, collected in a yellow-green outlet. It is combined with other leafy salads, as well as thyme, garlic, shrimp, meat snacks, cheese.

- iceberg in shape resembles a head of cabbage, it is the crispiest salad. It is combined with vegetable, meat, fish dishes, sandwiches. This salad allows you to use rather fat seasonings, for example, based on mayonnaise or blue cheese.

- butterhead - an oily salad, leaves are dark green in color, taste sweetly sweet. It contains a large amount of vitamin $\mathrm{E}$, during storage it accumulates the amount of nitrates. It is used mainly as a seasoning for dishes, can be used as an analogue of nori for sushi.

- radicchio - red chicory, bitter in taste, red-violet in color with white veins. Add to hot meat, vegetable dishes. In combination with mayonnaise, citrus dressings, it is added to salad mixes.

No less popular in cooking are new types of onion vegetables:

- shallots with a sweet, delicate taste, pleasant delicate smell. It is used in fresh, salted, pickled form.

- shnitt is a dark green styly feathers, has a soft onion aroma. It's used as an ingredient in cold sauces, as well as for decoration of dishes. 
- fragrant onion has leaves of dark green color, white inflorescences, garlic to taste and aroma, without spiciness. It's used in Asian cuisine, combined with soy sauce and fish dishes.

- wild garlic - it tastes like a cross between onion and garlic. It's use for soups, salads, savorypastries.

New types of mushrooms have also spread:

- portobello - a hat with a diameter of $12-15 \mathrm{~cm}$, in appearance resembles mushrooms, fleshy, only a hat is eaten, it tastes like poultry meat. It's used in the preparation of meat dishes, julienne, salads, for baking, you can stuff.

- shiitake - a hat with a diameter of 5 to $15 \mathrm{~cm}$, cracks on the surface of the hat; the taste is classic mushroom (something between mushrooms and honey mushrooms). It is combined with noodles, rice, it is used in the preparation of soups, sauces, salads, snacks.

- enoki - snow-white mushrooms on a long leg with small hats, reminiscent of egg yolk to taste. They are used for dishes of cuisines of China, Korea and Thai; they come to us in marinated form, where they are used in sushi.

- truffle - France is the birthplace of these mushrooms. Weight can reach $1 \mathrm{~kg}$. Distinguish between white and black truffles. White truffle has a garlic flavor and is more appreciated in cooking, while black truffle resembles something between alcohol and chocolate. It's served them to snails, oysters and seafood.

The creation of new unique tastes and aromas of ready meals and products is facilitated by the use of various spices and spices in the preparation. Spices - herbal products with a specific aroma and taste, containing essential oils, glycosides and alkaloids. These include:

- azhgon (zira) - fruits and herbs have a sharp taste and spicy aroma. It is part of the Indian curry mixture, it is added to vegetable and meat dishes, sauces, salads.

- airy oil is added to the dough product to give it a pleasant smell, as well as in the manufacture of fruit water aromatization of sweet dishes, jellies, mousses.

- Anise gives a fresh taste to any dish. It is combined with apples, added during the preparation of kvass, compotes, jelly. It's used to neutralize extraneous tastes and aromas in cooking.

- Star anise has a bitter-sweet taste, rich and complex aroma. Ideal for baking, preparing marinades, sauces, tinctures, adding to coffee and cocoa. Also used in the preparation of puddings, mousses, curd pastes. It's used in the preparation of poultry dishes, when frying pork and lamb.

- oregano (oregano) - added to soups, sauces, dishes of fried, stewed, baked meat, pizza.

- ginger goes well with drinks (mulled wine, punch, warming teas), pastries and, of course, sushi. It's used seasoning for fish, poultry. 
- turmeric has a mild flavor and resembles a little pepper and a bit vanilla. It's used in confectionery to give color and aroma to the product, also used in the preparation of meat, fish and vegetable dishes. It's used in curry.

- thyme has a pleasant steady smell and spicy bitter taste. It's improved the taste and smell of vegetable dishes, especially from potatoes and cabbage. They are seasoned with poultry, rabbit, offal and lamb dishes.

- fennel blends perfectly with white fish, and is also used as a side dish for pork, combined with chocolate.

- tarragon (tarragon) in appearance resembles wormwood, has a strong spicy and spicy taste. Stalksarepickled, salted. It's used to salads, appetizers, side dishes to meat and egg dishes.

Conclusions. New and non-traditional types of raw materials and food products used in the technology of preparing catering products were studied based on the analyzed literature. An opinion has been formed that new types of food raw materials are actively included in the work of public catering facilities, with the aim of improving the aesthetic and taste properties of prepared dishes.

\section{REFERENCES}

1. Aktual'nye napravleniia $\mathrm{v}$ razrabotke i sovershenstvovanii assortimenta goriachei kulinarnoi produktsii s uchetom tipa organizatsii pitaniia, eespetsializatsii [Actual direction sin the development and improvement of the range of hot culinary products, takingin to account the type of catering, its specialization]. (n. d. ) infourok. ru. https:/infourok. ru/lekciya-aktualnie-napravleniya-v-razrabotke-i-sovershenstvovanii-assortimentagoryachey-kulinarnoy-produkcii-s-uchetom-tipa-orga-3593970/

2. Dolgopolova S. V. New culinary technologies. Restaurant sheets, 2015. 272 p.

3. Sharokhina S. V., Gorokhovitskaya T. N. Innovations in the field of public catering, as a factor of strategic management. Internet-journal «ScienceofScience». 2017. Vol. 9. Is. 5. P. 5-17. 